\title{
Embryonic Expression of the Myelin Basic Protein Gene: Identification of a Promoter Region That Targets Transgene Expression to Pioneer Neurons
}

\author{
Charles F. Landry, ${ }^{1}$ Thomas M. Pribyl, ${ }^{1}$ Julie A. Ellison, ${ }^{1}$ M. Irene Givogri, ${ }^{1}$ Kathy Kampf, ${ }^{1}$ \\ Celia W. Campagnoni, ${ }^{1}$ and Anthony T. Campagnoni ${ }^{1,2}$ \\ ${ }^{1}$ Developmental Biology Group, Neuropsychiatric Institute, and ${ }^{2}$ Brain Research Institute, University of California at Los \\ Angeles, School of Medicine, Los Angeles, California 90024
}

The myelin basic protein (MBP) gene produces two families of structurally related proteins from three different promoters-the golli products, generated from the most upstream promoter, and the MBPs, produced from the two downstream promoters. In this report we describe the expression of golli proteins within some of the earliest neuronal populations of the brain, including Cajal-Retzius cells and preplate neurons of the forebrain, representing a new marker for these cells. To identify elements responsible for neuronal expression of the golli products, we generated transgenic animals from constructs containing different portions of the upstream promoter. A construct containing $1.1 \mathrm{~kb}$ immediately upstream of the golli transcription start site targeted expression of $\beta$-galactosidase to preplate neurons and a subset of Cajal-Retzius cells in transgenic mice-the first reported genetic element to target expression to these pioneer cortical populations. Although expression in Cajal-Retzius cells declined with embryonic development, preplate cells continued to express the transgene after arriving at their final destination in the subplate. Interestingly, expression persisted in subplate neurons found within a distinct layer between the white matter and cortical layer VI well into postnatal life. Birth dating studies with bromodeoxyuridine indicated that these neurons were born between E10.5 and E12.5. Thus, the transgene marked subplate neurons from their birth, providing a fate marker for these cells. This work suggests a role for the MBP gene in the early developing brain long before myelination and especially in the pioneer cortical neurons important in the formation of the cortical layers.

Key words: subplate neurons; Cajal-Retzius neurons; pioneer neurons; golli-mbp gene; promoter elements
Myelin proteins are among the most abundant in the nervous system, and, generally, they have been considered to be expressed only in myelin-forming cells. One of the two major classes of myelin proteins is the myelin basic proteins (MBPs), a family of proteins derived by alternative splicing of the MBP gene. Recently, the MBP gene structure has been found to be larger and more complicated than originally conceived (Campagnoni et al., 1993; Pribyl et al., 1993). This transcription unit, which we called the golli-mbp gene, is $\sim 105 \mathrm{~kb}$ in mice; its structure and the two families of products it encodes are shown in Figure 1. The golli mRNAs are produced from the most upstream promoter at the first transcription start site (tss1). The MBP mRNAs are produced from two downstream promoters: tss2, which gives rise to the M41-MBP mRNA, and tss3, which produces the majority of the MBP mRNAs.

The golli-mbp gene structure is unusual in many respects. It

Received March 6, 1998; revised June 23, 1998; accepted June 29, 1998.

This work was supported by National Institutes of Health Grants NS23022 and NS33091 and National Multiple Sclerosis Society Grants RG2233 and RG2693. We thank Vance Handley for assistance in managing the transgenic lines and optimizing the lac $Z$ staining, and Edwina Skinner and Lauren Cherman for assistance with tissue preparation. We also thank Dr. André M. Goffinet for providing us with reelin monoclonal antibody.

C.F.L. and T.M.P. contributed equally to this work.

Correspondence should be addressed to Dr. A. T. Campagnoni, MRRC/NPI, Room 47-448, University of California at Los Angeles, School of Medicine, 760 Westwood Plaza, Los Angeles, CA 90024.

Dr. Pribyl's present address: Digital Gene Technologies, La Jolla, CA 92037.

Dr. Ellison's present address: SmithKline Beecham Pharmaceuticals, King of Prussia, PA 19406

Copyright (C) 1998 Society for Neuroscience $0270-6474 / 98 / 187315-13 \$ 05.00 / 0$ numbers among the relatively small group of genes $>100 \mathrm{~kb}$ and is an example of a very rare arrangement of overlapping genes. For example, the transcription unit defining BG21, the most abundant golli product, extends from exon 1 to exon $5 \mathrm{C}$, overlapping both MBP transcription units. On the other hand, the transcription unit defining golli J37 extends from exon 1 to exon 11, completely encompassing the entire MBP transcription unit. The MBP and BG21 portions of the golli- $m b p$ gene are not simply included within an intron of the larger gene, but they share alternatively spliced exons in common. This type of alternative splicing in overlapping transcription units of this size is very unusual.

Another unusual feature of the golli-mbp gene is its regulation. Tss 3 is under tight developmental and cellular control and is active only in myelin-forming cells. There is evidence that this regulation resides solely within the promoter for tss3 (GoujetZalc et al., 1993). In contrast, tss1, which controls the expression of golli products, appears to be under less stringent cellular control because it is expressed in selected populations of neurons, in oligodendrocytes in the postnatal brain, and in cells and tissues of the immune system (Pribyl et al., 1993; Fritz and Kalvakolanu, 1995; Landry et al., 1996; Pribyl et al., 1996a,b). Nothing is known about golli expression in the mouse embryonic nervous system.

The goals of this study were to define the cellular expression of golli mRNAs and proteins in the embryonic nervous system and to identify promoter elements that specified the cell and developmental expression of the golli promoter in the nervous system. We found extensive expression of golli in neurons within the embryonic CNS and peripheral nervous system (PNS). Trans- 


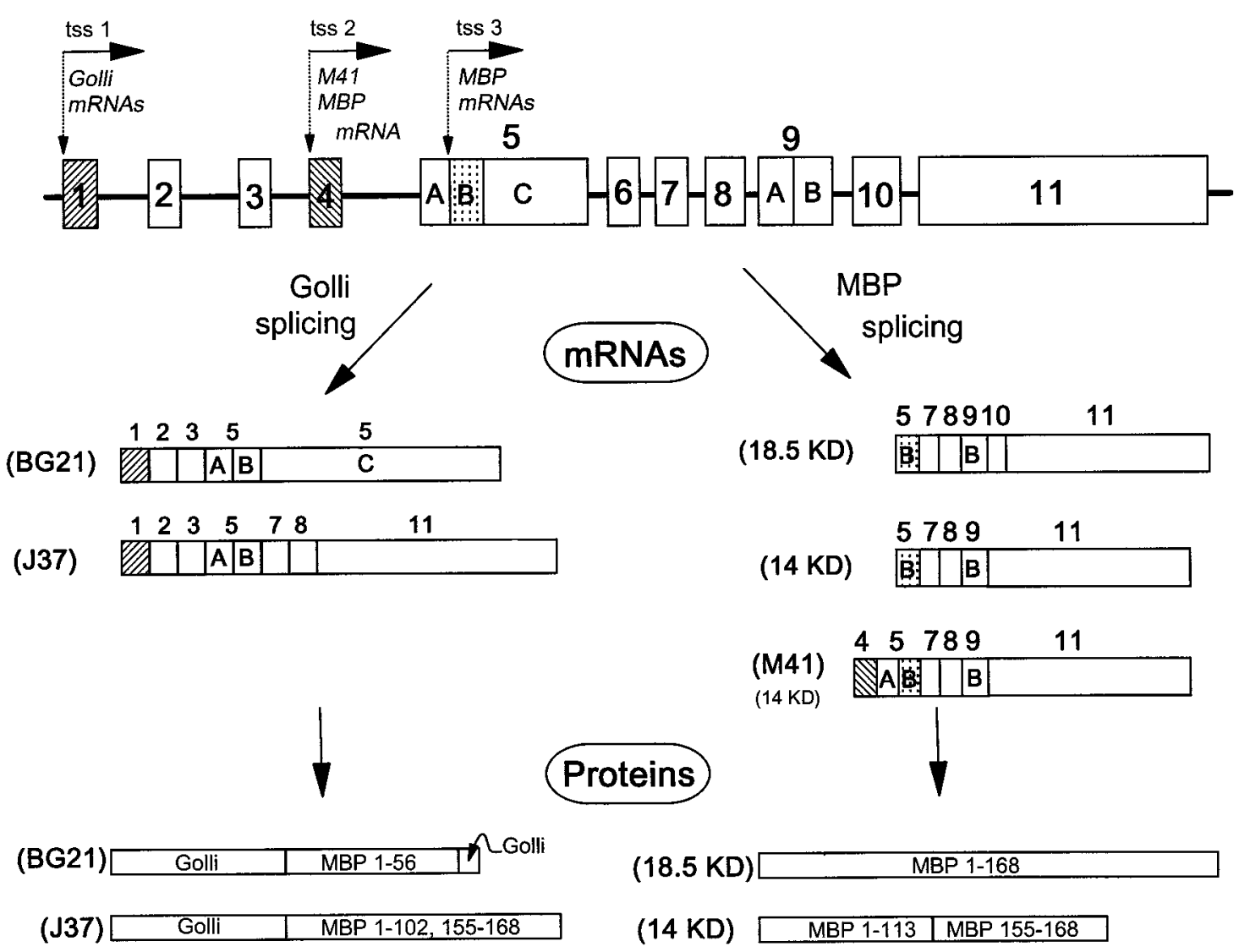

Figure 1. Diagrammatic representation of the myelin basic protein gene and the golli and "classic" MBP products generated from this gene. The MBP gene contains three transcription start sites (tss) that produce either golli products (tss 1 ) or MBP products (tss 2 and tss3). The two major golli mRNA and protein products $(B G 21$ and $J 37)$ and the major MBP products (including M41) are indicated. Note that the golli proteins $B G 21$ and $J 37$ contain unique golli sequences fused to MBP peptide sequences.

genic studies permitted us to identify a 1100 bp genomic region that targeted expression to only a subset of those neurons in the embryonic forebrain and the PNS. One of these groups of neurons included pioneer neurons, i.e., preplate neurons, for which such specific targeting elements previously have not been reported. Furthermore, expression of the transgene was not transient but continued in most groups of neurons well into postnatal development, thereby providing a marker for the developmental history of these neuronal cell types.

\section{MATERIALS AND METHODS}

\section{Probes}

The cDNA clones used in Northern blot analysis included an 0.5 kilobase (kb) mouse golli cDNA insert encompassing golli exons 1-3 and part of exon 5a (Campagnoni et al., 1993) and a $0.9 \mathrm{~kb}$ cyclophilin cDNA from the plasmid p1B15 (Danielson et al., 1988). The cDNA clones used for Southern blotting included a $3.5 \mathrm{~kb} \beta$-galactosidase insert (NotI-Not I fragment) from pNASS $\beta$ (Clontech, Palo Alto, CA) and a $2.5 \mathrm{~kb}$ cDNA insert encoding glial fibrillary acidic protein (GFAP). cDNA inserts were labeled with $\left[\alpha^{-32} \mathrm{P}\right] \mathrm{CTP}$, using random oligonucleotides as primers (Feinberg and Vogelstein, 1983).

\section{Northern and Southern blotting}

Northern blots. RNA from embryonic or postnatal brain was isolated by the guanidinium thiocyanate method and purified through a cesium chloride gradient (MacDonald et al., 1987). Poly(A ${ }^{+}$) RNA was selected by means of an oligo-dT-cellulose column (Jacobson, 1987), and Northern blots were prepared as described previously (Campagnoni et al., 1994). A cDNA specific to the golli portion of the golli mRNAs (exons 1-3) was used as a probe.
Southern blots. Genomic DNA was isolated from transgenic mouse tails by digesting $\sim 1 \mathrm{~cm}$ of tail in $600 \mu$ l of $50 \mathrm{~mm}$ Tris, pH $8.0,100 \mathrm{~mm}$ EDTA, $0.5 \%$ SDS, and $0.8 \mu \mathrm{g} / \mathrm{ml}$ proteinase $\mathrm{K}$ overnight at $50^{\circ} \mathrm{C}$. After phenol/chloroform (1:1) extraction, $50 \mu \mathrm{g} / \mathrm{ml}$ RNase was added; the solution was incubated for $2 \mathrm{hr}$ at $37^{\circ} \mathrm{C}$, extracted once with phenol/ chloroform and once with chloroform, and precipitated by the addition of absolute ethanol. The resulting DNA pellet was resuspended in $10 \mathrm{~mm}$ Tris, $\mathrm{pH}$ 8.0, and 1 mM EDTA.

Southern blotting was performed essentially as described previously (Verity et al., 1993), except that MagnaGraph membranes (Micron Separations, Westborough, MA) were used for blotting. Also, blots were hybridized overnight at $68^{\circ} \mathrm{C}$ in a solution containing $500 \mathrm{~mm} \mathrm{NaPO}_{4}, \mathrm{pH}$ 7, $1 \% \mathrm{BSA}, 7 \%$ SDS, $1 \mathrm{~mm}$ EDTA, and from 3 to $5 \times 10^{6} \mathrm{dpm} / \mathrm{ml}$ random-prime-labeled cDNA probe.

\section{Western blots}

The protein fraction was isolated from tissue by using Triazol reagent (Life Technologies, Gaithersburg, MD) according to the manufacturer's instructions. Aliquots $(100 \mu \mathrm{g})$ dissolved in $10 \%$ SDS were diluted with an equal volume of $8 \mathrm{~m}$ urea, $125 \mathrm{~mm}$ Tris, $\mathrm{pH} 6.8,4 \%$ SDS, and $3 \%$ DTT, were allowed to stand at room temperature for at least $15 \mathrm{~min}$, and were loaded on a $12 \%$ Laemmli gel. After transfer to nitrocellulose, the blotted proteins were incubated overnight at $4^{\circ} \mathrm{C}$ with golli-specific antibodies; the golli proteins were detected with the Pierce Super-Signal system (Rockford, IL).

\section{Vector construction for transgenic lines}

A $6.6 \mathrm{~kb} \mathrm{BamHI}$ genomic fragment that included the first $220 \mathrm{bp}$ of golli exon 1 was isolated and cloned into the XhoI site of pNASS $\beta$. The $B a m \mathrm{HI}$ and $\mathrm{XhoI}$ sites were made compatible by performing a two-base end-fill reaction. After ligation and transformation the recombinant plasmid was isolated, digested with EcoRI to remove $5.3 \mathrm{~kb}$ of distal 
mouse genomic sequence, and then religated. This new recombinant plasmid now contained $1.3 \mathrm{~kb}$ of mouse genomic DNA (1.1 kb of golli gene promoter plus 220 bp of golli exon 1), followed by an SV40 splice donor-acceptor site, the $\beta$-galactosidase gene, and a polyadenylation signal. The recombinant plasmid was digested with $S c a$ I-SphI to remove excess plasmid DNA, and the resulting insert $(6.1 \mathrm{~kb})$ was purified by agarose gel electrophoresis. The production of the transgenic founders was performed by the UCLA Transgenic Core Facility (Los Angeles, CA).

\section{Analysis of transgenic animals}

Founders. Transgenic mouse lines were identified by Southern blot analysis of isolated tail DNA. Founder lines stably transmitted the transgene with Mendelian inheritance, as assessed by Southern analysis. Estimates of the copy number of the transgene in transgenic lines were made by comparing the strengths of the hybridization signals of the $\beta$-galactosidase probe with those of a known single-copy gene probe (GFAP). Progeny screened from every generation that was examined exhibited no detectable change in transgene copy number.

$\beta$-Galactosidase activity in tissue extracts. Animals were anesthetized with barbiturates (halothane) and killed by cervical dislocation. Tissues were removed and immediately homogenized for $20 \mathrm{sec}$ in a Polytron PT3000 (Brinkmann, Westbury, NY) at 15,000 rpm in 1-2 ml of $100 \mathrm{~mm}$ $\mathrm{KHPO}_{4}$, pH 7.8, 0.2\% Triton X-100, 1 mM dithiothreitol, $0.2 \mathrm{~mm}$ phenylmethylsulfonylfluoride, and $5 \mu \mathrm{g} / \mathrm{ml}$ leupeptin. The homogenates were centrif uged in a microf uge $(14,000 \mathrm{rpm})$ for $5 \mathrm{~min}$. The supernatant was assayed for $\beta$-galactosidase activity by the Galacto-Light Chemiluminescent Reporter assay (Tropix, Bedford, MA). Reactions were performed with 5-15 $\mu \mathrm{g}$ of protein for $30 \mathrm{~min}$ at room temperature, and the light emissions were read in a luminometer. Protein determinations were made with a detergent-compatible protein assay (Bio-Rad, Hercules, CA).

$\beta$-Galactosidase staining of embryonic mouse tissues. Timed-pregnant females were anesthetized and killed by cervical dislocation. Embryos were removed, rinsed briefly in ice-cold PBS, and incubated for $1 \mathrm{hr}$ at $4^{\circ} \mathrm{C}$ in fixative solution ( $2 \%$ formaldehyde, $0.2 \%$ glutaraldehyde, and 0.1 $\mathrm{M} \mathrm{NaHPO}, \mathrm{pH}$ 7.3) with gentle agitation. Then the embryos were washed three times with rinse solution $(0.01 \%$ sodium deoxycholate, $0.02 \% \mathrm{NP}-40,2 \mathrm{mM} \mathrm{MgCl}$, and $\left.0.1 \mathrm{M} \mathrm{NaHPO}_{4}, \mathrm{pH} 7.3\right)$ and then placed in X-gal stain solution [containing (in $\mathrm{mM}) 2 \mathrm{MgCl}_{2}, 5 \mathrm{~K}_{3} \mathrm{Fe}(\mathrm{CN})_{6}$, and $5 \mathrm{~K}_{4} \mathrm{Fe}(\mathrm{CN})_{6}$, plus $0.1 \mathrm{M} \mathrm{NaHPO}_{4}, \mathrm{pH} 7.3,0.01 \%$ sodium deoxycholate, $0.02 \% \mathrm{NP}-40$, and $8 \mathrm{mg} / \mathrm{ml} \mathrm{X}$-gal (5-bromo-4-chloro-3-indolyl- $\beta$-Dgalactoside)] for $12-16 \mathrm{hr}$ at $37^{\circ} \mathrm{C}$. Stained embryos were rinsed and equilibrated in sucrose solution $\left(20 \%\right.$ sucrose, $0.05 \% \mathrm{NaN}_{3}$, and $0.1 \mathrm{M}$ $\mathrm{NaHPO}_{4}, \mathrm{pH} \mathrm{7.3)}$ at $4^{\circ} \mathrm{C}$.

$\beta$-galactosidase staining in postnatal mice. Postnatal transgenic mice were killed and perfused as described (Landry et al., 1996). Then the brains were removed and rinsed in ice-cold $0.1 \mathrm{M} \mathrm{NaHPO}_{4}, \mathrm{pH}$ 7.3. The entire brain was cut into 1 -mm-thick slices, processed with fixative, rinsed, and stained identically to the embryos. After equilibration in sucrose, the brain slices were embedded in OCT embedding compound, frozen at $-20^{\circ} \mathrm{C}$, cut into $20 \mu \mathrm{m}$ cryostat sections, and mounted on slides.

Bromodeoxyuridine birth dating and detection. Timed-pregnant female mice were injected intraperitoneally with $100 \mu \mathrm{g} / \mathrm{gm}$ body weight of 5-bromo-2'-deoxyuridine (BrdU) in sterile PBS. At specific ages after birth, the animals were perfused and processed as described below. Cryostat sections $(20 \mu \mathrm{m})$ from forebrain were incubated in X-gal staining solution for $2 \mathrm{hr}$ at $37^{\circ} \mathrm{C}$, preincubated in $2 \mathrm{~N} \mathrm{HCl}$ for $30 \mathrm{~min}$ at $65^{\circ} \mathrm{C}$, and then incubated overnight in anti-BrdU monoclonal antibody (Becton Dickinson, San Jose, CA). Detection of the antibody was performed with the Vectastain Elite $\mathrm{ABC}$ reagents and peroxidase substrate according to the manufacturer's instructions (Vector Laboratories, Burlingame, CA).

\section{Immunocytochemistry}

Frozen cryostat sections $(20 \mu \mathrm{m})$ of transgenic or normal mouse brain tissue were prepared and processed for immunohistochemistry as described (Landry et al., 1996). Postnatal animals were killed and perfused with $4 \%$ paraformaldehyde (PBS-buffered); the brain tissue was equilibrated in sucrose solution, frozen in OCT, and sectioned. Whole embryos were emersion-fixed in $2 \%$ paraformaldehyde (PBS-buffered) for $12 \mathrm{hr}$, frozen in OCT, and sectioned. The mounted sections were stained with polyclonal antibodies against GFAP (1:1000; Chemicon, Temecula, CA), tau protein (1:2000; Chemicon), calretinin (1:1000; Chemicon), golli protein (1:5000; Landry et al., 1996), or a monoclonal antibody against reelin (1:1500; a gift kindly provided by Dr. André M. Goffinet, University of Namur, Belgium). Immunocytochemistry was visualized with the Vectastain Elite ABC reagents and peroxidase substrate according to the manufacturer's instructions (Vector Laboratories). To combine $\beta$-galactosidase staining with immunocytochemistry, we first treated sections with X-gal staining solution for $2 \mathrm{hr}$ to overnight $\left(37^{\circ} \mathrm{C}\right)$ and then processed them for immunocytochemistry as described above. Double immunofluorescence was performed by incubating the tissue overnight $\left(4^{\circ} \mathrm{C}\right)$ in the presence of golli polyclonal $(1: 1500)$ and reelin monoclonal (1:1500) antibodies. Detection was with anti-rabbit fluorescein or antimouse rhodamine (Boehringer Mannheim, Indianapolis, IN) to detect anti-golli or anti-reelin antibody, specifically. Images from fluorescent staining were obtained on a Zeiss LSM 310 laser-scanning confocal microscope (Oberkochen, Germany).

\section{In situ hybridization}

The tissue preparation, ${ }^{33} \mathrm{P}$-labeled cRNA probe synthesis, and in situ hybridizations were performed as described by Ellison et al. (1996). Embryos were removed from pregnant females after anesthesia and cervical dislocation and immersion-fixed in $2 \%$ paraformaldehyde in PBS for $5 \mathrm{~d}$ at $4^{\circ} \mathrm{C}$. Then the embryos were rinsed and equilibrated in sucrose solution, embedded in OCT embedding compound, and frozen at $-80^{\circ} \mathrm{C}$. The embryos were sectioned sagittally at $10-14 \mu \mathrm{m}$, mounted on Superfrost slides (Fisher Scientific, Pittsburgh, PA), and stored at $-80^{\circ} \mathrm{C}$ until used. Golli-specific sense and antisense ${ }^{33} \mathrm{P}-\mathrm{UTP}$-labeled riboprobes (corresponding to exons 2,3 , and 5a) were synthesized from linearized plasmids. The specific activity of the probes ranged from 1 to $2 \times 10^{9} \mathrm{cpm} / \mu \mathrm{g}$. The tissue sections were hydrated and then treated as follows: $0.2 \mathrm{M} \mathrm{HCl}$ for $10 \mathrm{~min} ; 3 \mu \mathrm{g} / \mathrm{ml}$ proteinase $\mathrm{K}$ in $10 \mathrm{~mm}$ Tris and $1 \mathrm{~mm}$ EDTA, $\mathrm{pH} 8.0$, for $10 \mathrm{~min}$; and $0.1 \mathrm{~m}$ triethanolamine, $\mathrm{pH} 8.0$, and $0.25 \%(\mathrm{v} / \mathrm{v})$ acetic anhydride for $10 \mathrm{~min}$. Finally, the sections were dehydrated through a graded ethanol series. Then the tissue sections were prehybridized for $2 \mathrm{hr}$ at $60^{\circ} \mathrm{C}$ in $1 \times$ hybridization buffer [ $4 \times \mathrm{SET}$ $(600 \mathrm{~mm} \mathrm{NaCl}, 4 \mathrm{~mm}$ EDTA, and $80 \mathrm{~mm}$ Tris, pH 7.8)/1× Denhardt's solution, $0.2 \%$ SDS, $100 \mathrm{~mm}$ DTT, $250 \mu \mathrm{g} / \mathrm{ml}$ tRNA, $25 \mu \mathrm{g} / \mathrm{ml}$ each of poly $\left(\mathrm{A}^{+}\right)$and poly-C/1 U/ $\mu \mathrm{l}$ RNasin (Promega, Madison, WI), and 50\% formamide]. The slides were incubated in $1 \times$ hybridization buffer and $10 \%$ dextran-sulfate containing $0.2 \mathrm{ng} / \mu \mathrm{l} \mathrm{cRNA}$ probe overnight at $60^{\circ} \mathrm{C}$ in a humid chamber. Posthybridization washes were $4 \times \mathrm{SSC}$ at room temperature (RT); $2 \times \mathrm{SSC}$ at RT, $20 \mu \mathrm{g} / \mathrm{ml} \mathrm{RNase} A$ at RT, $2 \times \mathrm{SSC}$ at $\mathrm{RT}, 0.1 \times \mathrm{SSC}$ at $55^{\circ} \mathrm{C}$, and $0.5 \times \mathrm{SSC}$ at RT. Slides then were dehydrated in an ascending ethanol series containing $300 \mathrm{~mm} \mathrm{NH}_{4} \mathrm{OAc}$, with a final dehydration in $100 \%$ ethanol. Last, the slides were exposed to Hyperfilm $\beta$-Max (Amersham, Arlington Heights, IL).

\section{RESULTS}

\section{Golli products, under the control of tss 1 , are expressed throughout the developing mouse embryo as early as E11}

\section{Differential expression of golli $m R N A$ splice products in the developing brain}

We previously reported that the first tss 1 of the golli-mbp transcription unit generates golli products that are expressed in postnatal neurons (Landry et al., 1996), oligodendrocytes (Pribyl et al., 1996a), and cells of the immune system (Pribyl et al., 1996b). To extend these studies, we determined the time course of expression of the golli products in the mouse embryo. From Northern blot analyses we found that golli mRNAs were expressed in developing mouse brain at the earliest age examined, i.e., embryonic day 14 (E14) (Fig. 2A) Brain poly $\left(\mathrm{A}^{+}\right)$RNA isolated from a number of ages was probed with a golli exon-specific construct that detected golli mRNAs, but not MBP mRNAs (see Materials and Methods). Northern analysis indicated that the predominant transcript expressed in the embryonic CNS was BG21, encoded by a $5.1 \mathrm{~kb}$ mRNA. The golli J37 mRNA $(2.6 \mathrm{~kb})$ became more evident in the postnatal brain. These findings were corroborated by Western blot analysis (Fig. $2 B$ ), which showed that the expression of BG21 protein began between E13 and E18 and continued into postnatal life. Levels of J37 were too low to detect in the Western blots, as indicated earlier (Landry et al., 1996). 
A

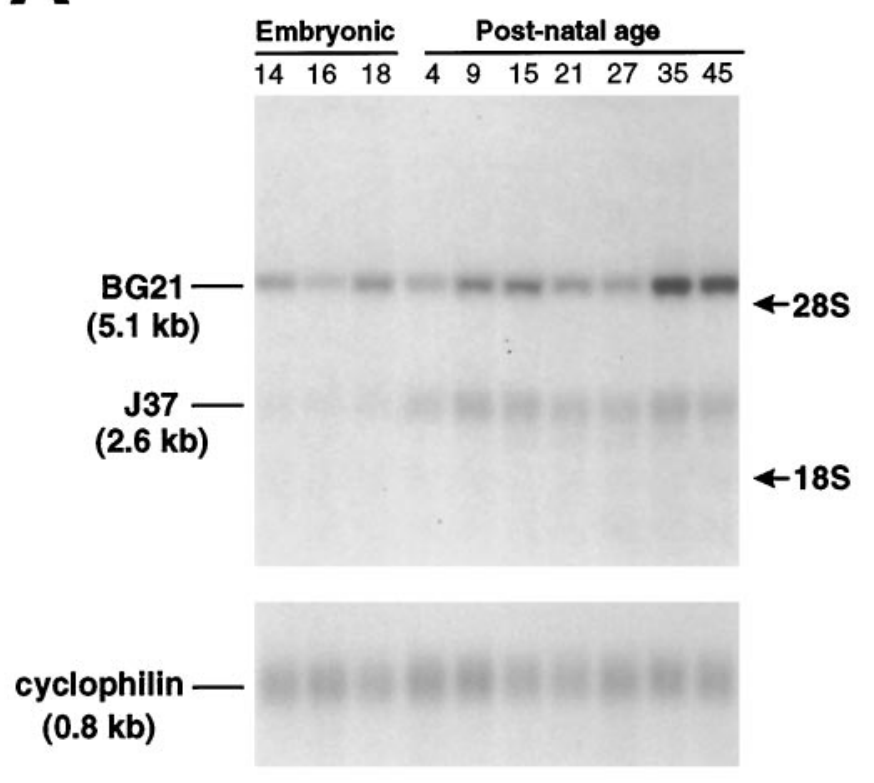

B

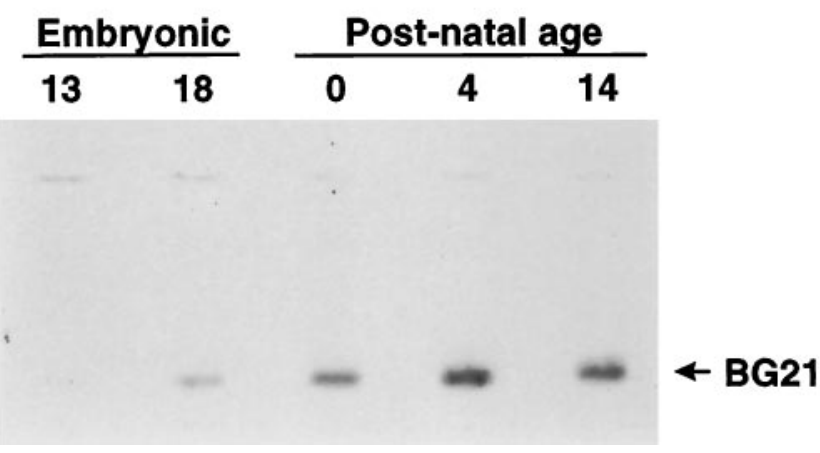

Figure 2. Developmental Northern and Western blots depicting the major golli products in embryonic and postnatal mouse brain. $A$, Poly $\left(\mathrm{A}^{+}\right)$mRNA from mouse brain isolated at various embryonic and postnatal ages was electrophoresed, blotted, and probed with a gollispecific cDNA. BG21 mRNA (5.1 kb) was present in mouse brain at E14, the earliest age that was examined. J37 mRNA (2.6 kb) was not evident until just before birth. Reprobing the blot for cyclophilin $(0.8 \mathrm{~kb})$ was used to assess the equal loading of poly $\left(\mathrm{A}^{+}\right)$in the lanes. Migration distances for the $28 \mathrm{~S}$ and $18 \mathrm{~S}$ ribosomal bands (arrows) are indicated. $B$, Protein extracted from either whole head (E13) or brain was electrophoresed and stained with antibody to golli protein. A single $31 \mathrm{kDa}$ band that comigrated with full-length recombinant BG21 peptide (lane not shown) was evident by E18 and accumulated during postnatal development.

\section{In situ hybridization histochemical studies}

To determine the regional distribution of golli mRNA expression in the developing fetal mouse, we examined sections from wholemouse embryos hybridized with a golli-specific cRNA probe (Fig. $3)$. As predicted from Northern analysis, golli mRNA was expressed throughout the embryonic brain, including the telencephalon (T), mesencephalon (M), and rhombencephalon (R) (Fig. $3 A)$. In the E11.5 embryo, golli mRNA expression also was found in the olfactory epithelium (OE), dorsal and ventral gray matter of the spinal cord (d/v GM), and the dorsal root ganglia (DRG).
Expression in other tissues such as the liver (Li) was also evident. The specificity of the antisense probe can be seen by comparison with the sense probe, shown in Figure $3 B$.

By E15.5, golli mRNA expression was clearly evident outside the nervous system, including the thymus $(\mathrm{Th})$, gut $(\mathrm{G})$, lung $(\mathrm{Lu})$, and kidney $(\mathrm{K})$ (Fig. 3C). Except for the thymus, golli mRNA expression in these tissues was found to be attributable to expression within neuroendocrine cells or in peripheral neurons and their fibers innervating these tissues (Landry et al., 1997). In the E15.5 brain, golli mRNA continued to be expressed in cell populations within the forebrain $(\mathrm{F})$, the midbrain $(\mathrm{M})$, brainstem, and OE (Fig. 3C).

\section{Golli proteins are expressed in pioneer neuronal populations in the embryonic mouse brain}

To identify the cell types that express golli protein in the embryonic brain, we used a monospecific polyclonal antibody generated against the 133 amino acid region that is specific to golli proteins (Landry et al., 1996). In agreement with in situ hybridization data, golli protein immunoreactivity was evident within all major regions of the embryonic brain. The enhanced resolution provided by the immunocytochemical analysis permitted us to localize golli protein to neuronal cell bodies and processes. At E11.5, for example, golli protein was confined to early developing neuronal populations during the initial formation of axon systems. In the developing tectum, golli immunoreactivity was present in cell bodies (Fig. 4A, arrowheads) and axonal fibers (Fig. 4A, arrows) that coursed directly beneath the pial surface. Golli protein was also present within migrating cells of the olfactory placode (OP) (Fig. $4 B$ ) and OE (data not shown), in agreement with the in situ hybridization results.

Expression of golli protein in the developing cortex was especially interesting. During formation of the preplate in the neocortex, golli protein expression delineated the developing CajalRetzius neurons (CR) (Fig. 4B), which were present just below the pial surface of the telencephalon. At E11.5 a few cells with short processes were present; however, by E13.5 a well developed plexiform layer was evident (PP) (Fig. 4C). As the preplate was split by an expanding cortical plate, golli immunoreactivity was found to be localized to the marginal zone layer (MZ) and the subplate (SP). By E15.5, these two layers were stained clearly and specifically with antibody to golli protein (Fig. 4E), and the pattern of staining mirrored adjacent sections immunostained for calretinin (Fig. $4 F$ ), an early marker of cortical pioneer neuronal populations in the developing telencephalon (Fonseca et al., 1995). The presence of golli protein in Cajal-Retzius neurons was supported further by the colocalization of golli with the extracellular matrix protein, reelin (Fig. $4 G$, arrows), which is unique to Cajal-Retzius cells (D'Arcangelo et al., 1995; Ogawa et al., 1995).

\section{Expression of the $\beta$-galactosidase reporter in transgenic mice driven by the golli proximal promoter region}

Previous work in postnatal animals indicated that the expression of golli products occurs in oligodendrocytes and neurons within the CNS and in cells and tissues of the immune system. Because the expression of golli within these cell types and tissues begins during the earliest stages of tissue formation, we were interested in identifying genomic regions upstream of tss1 that might be involved in regulating expression specifically within the immune system and nervous system as well as within oligodendrocytes and neurons. To map out relatively large regions upstream of tss1, we 


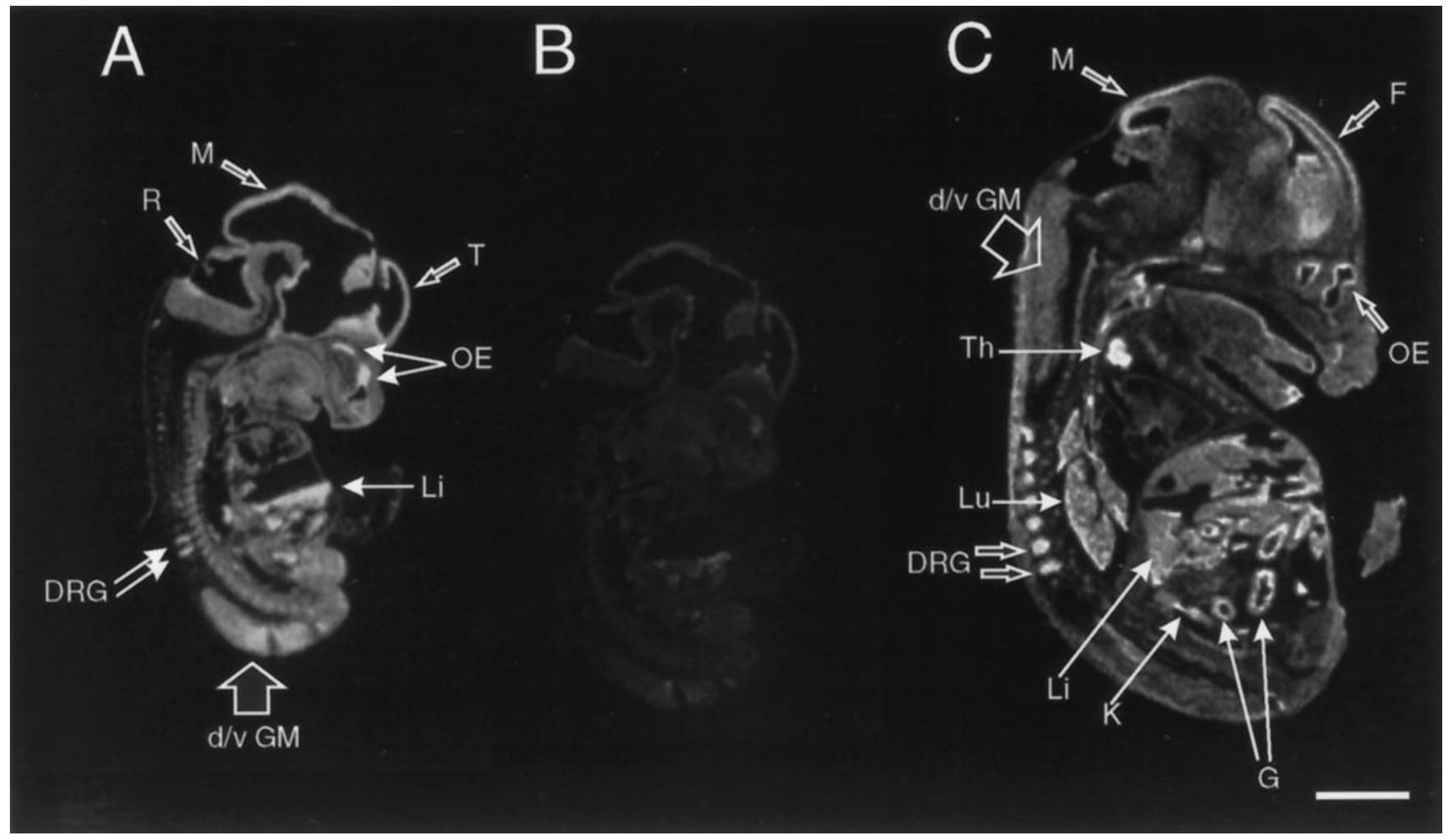

Figure 3. Expression of golli mRNA in the embryonic mouse, using in situ hybridization histochemistry. $A$, Sagittal section from an E11.5 embryo hybridized with a ${ }^{33} \mathrm{P}$-labeled golli-specific antisense probe. At this age, golli mRNAs were expressed in a number of regions within the central and peripheral nervous systems as well as within internal organs. $D R G$, Dorsal root ganglia; $d / v G M$, dorsal and ventral gray matter of the spinal cord; $L i$, liver; $M$, mesencephalon; $O E$, olfactory epithelium; $R$, rhombencephalon; $T$, telencephalon. $B$, An adjacent section to $A$ hybridized with a ${ }^{33} \mathrm{P}$-labeled sense probe did not label above background levels. $C$, In an E15.5 sagittal section hybridized with antisense probe to golli mRNA, labeling was evident within specific regions of the brain and spinal cord. Golli mRNA expression was also present within peripheral tissues, including the thymus (Th). Except for thymus, golli expression in peripheral tissues was found to correspond to golli protein within neuroendocrine cells and peripheral nerves (Landry et al., 1997). $D R G$, Dorsal root ganglia; $d / v G M$, dorsal and ventral gray matter of the spinal cord; $F$, forebrain; $G$, gut; $K$, kidney; $L i$, liver; $L u$, lung; $M$, midbrain; $O E$, olfactory epithelium. Scale bar: in $A, B, 1.9 \mathrm{~mm}$; in $C, 1.5 \mathrm{~mm}$.

isolated and mapped two genomic regions of $\sim 6.4$ and $\sim 1.1 \mathrm{~kb}$ upstream of tss 1 . We conducted preliminary studies in vitro to assess the activity of these constructs in some cell lines that expressed golli proteins and mRNAs and that included examples of neurons (i.e., PC12 and CN1.4-a conditionally immortalized mouse cortical neuronal line generated in our lab), oligodendrocytes (N20.1), and macrophages (RAW 264). We tested two constructs containing 0.9 and $6.4 \mathrm{~kb}$ of promoter sequence upstream of tss 1 plus the first 220 bp of exon 1 (subcloned into a vector containing a luciferase reporter) in these four cell lines (data not shown). In transient transfection assays the activity of the $1.1 \mathrm{~kb}$ golli promoter was almost 50-fold greater than the promoterless reporter plasmid, but there was relatively little luciferase activity in the other neuronal cell line (CN1.4), the oligodendroglial cell line (N20.1), or the macrophage line (RAW264). The $6.6 \mathrm{~kb}$ promoter exhibited the same pattern of expression, except that its activity in the PC12 cells was less than one-half that of the $1.1 \mathrm{~kb}$ promoter. The restricted activity of the 1.1 and $6.6 \mathrm{~kb}$ golli promoter constructs to PC12 cells suggested to us that these genomic regions might confer restricted expression (1) to the nervous system and/or (2) to certain subsets of neurons.

To investigate the expression directed by the golli proximal promoter region in vivo, we inserted a $1.3 \mathrm{~kb}$ fragment (containing $1.1 \mathrm{~kb}$ of promoter sequence and the first $220 \mathrm{bp}$ of exon 1) upstream of a promoterless lac $Z$ gene in the plasmid pNASS $\beta$ (shown in Fig. 5A), and this construct was used to generate transgenic mice. Five founder mice were obtained, three of which did not transmit the transgene. The remaining two, 1.3D and 1.3E, transmitted the transgene with a Mendelian inheritance pattern, and the lines established from each founder were bred to homozygosity. The independent nature of the two lines was established by Southern blot analysis of DNA from the 1.3D and 1.3E mice (Fig. $5 B$ ). By comparison of the hybridization signal of an unrelated single-copy gene with the hybridization signal of the lac $Z$ transgene, we estimate that the $1.3 \mathrm{D}$ and $1.3 \mathrm{E}$ mice contain three and five copies of the transgene per allele, respectively.

Tissues extracts were prepared from animals from both lines at two prenatal (E14 and E18) and three postnatal ages (P7, P21, and P60) and assayed for $\beta$-galactosidase (lac Z) activity (Fig. 6). Although the two lines were independent, the overall pattern of lac $Z$ expression in the 1.3D and 1.3E lines was identical. Between E14 and P60, significant activity was observed only in the brains, but not the thymuses, of both transgenic lines, establishing that the transgene was not expressed in the immune system. Interestingly, in the brain the peak expression of the gene appeared to occur at E18 in both lines and then declined with further development. When the postnatal brain tissue samples were dissected into the cortex and into the brainstem plus diencephalon $(\mathrm{BS}+\mathrm{DE})$, most of the activity was found in the cortex, and very little was observed in the remainder of the brain $(B S+D E)$. In 

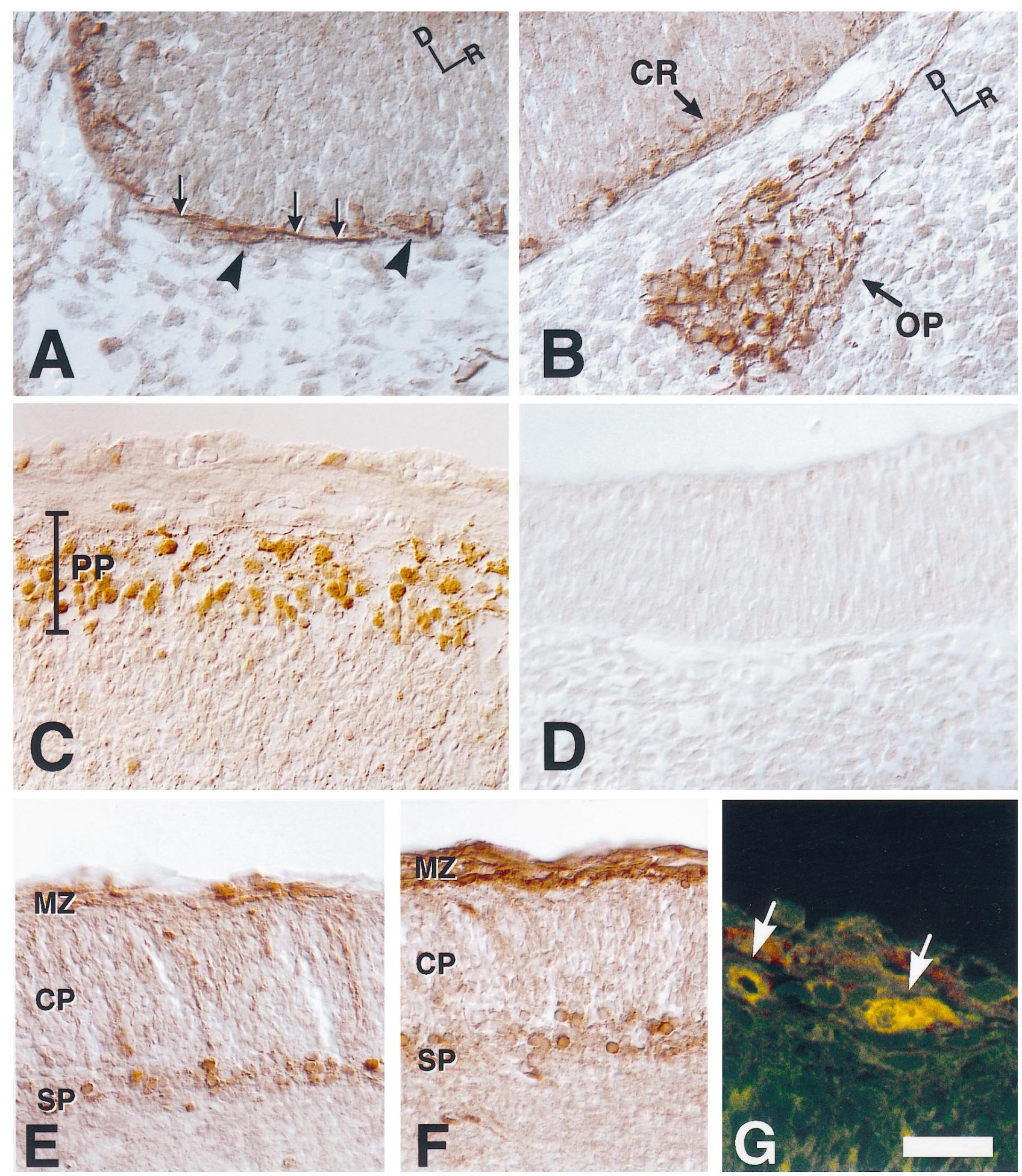

Figure 4. Golli protein is present in early developing neuronal systems within the embryonic mouse brain. $A$, Sagittal sections from E11.5 embryos were immunostained for golli protein by incubating the tissue with immunopurified golli-specific polyclonal antibody. Neuronal cell bodies (arrowheads) and axonal fibers (arrows), seen coursing directly beneath the pial surface in the developing tectum, stained intensely. Dorsal $(D)$ and rostral $(R)$ orientation markers are indicated. $B$, Golli immunoreactivity was evident within neurons of the olfactory placode $(O P)$ as well as within Cajal-Retzius $(C R)$ neurons at the pial surface of the E11.5 telencephalon. Dorsal $(D)$ and rostral $(R)$ orientation markers are indicated. $C$, Sagittal sections of E13.5 embryos at the level of the telencephalon showed prominent immunostaining of golli protein within the primordial plexiform layer $(P P$, preplate $) . D$, An E11.5 section incubated with antibody preabsorbed with golli peptide illustrates background. $E$, By E15.5, stain corresponding to golli protein was present within neurons of the subplate $(S P)$ and marginal zone $(M Z)$ of coronal sections. The cortical plate $(C P)$ was stained only lightly. $F$, An adjacent section to $E$ that was immunostained with antibody to the early neuronal marker calretinin. Note that the pattern of staining in the $M Z$ and $S P$ is very similar to sections that were stained with antibody to golli protein (see $E$ ). $G$, Coronal sections of E15.5 mouse brain were double-labeled with polyclonal antibody to golli protein and monoclonal antibody to the Cajal-Retzius marker reelin. Green and red corresponds to golli and reelin immunoreactivity, respectively. A colocalization of the proteins within a single neuron is indicated by yellow (arrows). Scale bar: in $A-C, E, F, 30 \mu \mathrm{m}$; in $D, 25 \mu \mathrm{m}$; in $G, 10 \mu \mathrm{m}$. 
A

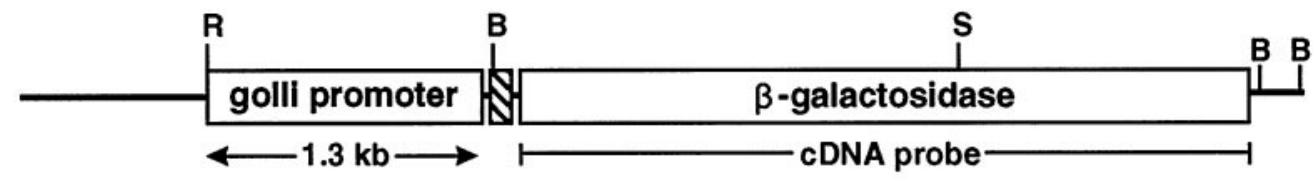

B

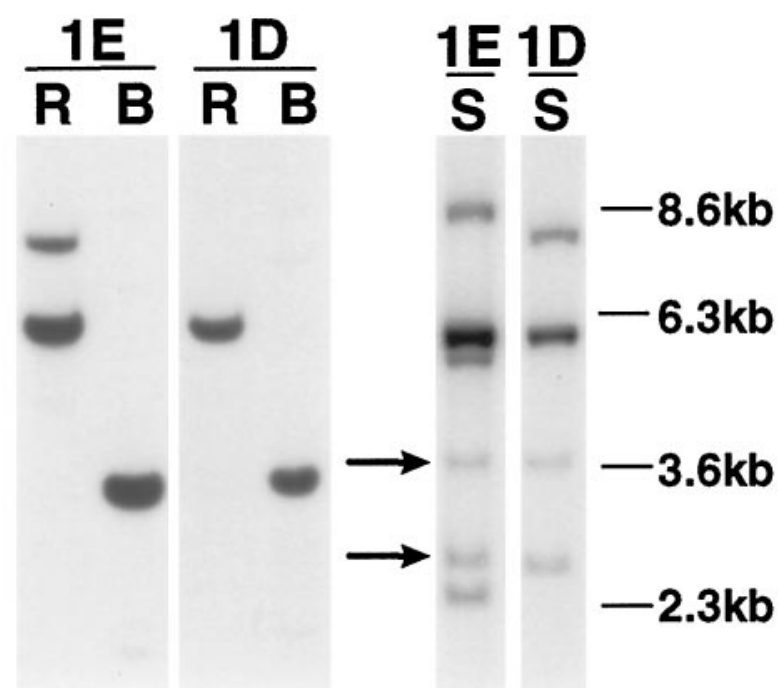

Figure 5. Diagrammatic representation of the golli promoter-driven reporter construct used in the generation of transgenic mice and Southern blots of transgenic lines $1 \mathrm{D}$ and $1 \mathrm{E}$. $A$, Schematic representation of the golli promoter expression construct that was used in the production of transgenic mice. The golli promoter fragment (shaded area) includes the first $220 \mathrm{bp}$ of golli exon 1 and $1.1 \mathrm{~kb}$ of genomic sequence immediately upstream of tss1. The hatched area represents an SV40 splice donor/splice acceptor site. Not shown is the polyadenylation signal that follows the $\beta$-galactosidase gene; $B, B a m \mathrm{HI} ; R, E c o$ RI; $S, S s t I$. $B$, Southern blots of transgenic mouse genomic DNA revealed multiple copies of the transgene inserted at independent sites in lines $1 E$ and $1 D$. DNA $(5 \mu \mathrm{m})$ from each line was digested with either EcoRI $(R)$ or BamHI $(B)$ in one experiment shown and with $S s t \mathrm{I}$ $(S)$ in another experiment shown. Lanes $R$ and $B$ were probed with $\beta$-galactosidase cDNA whereas lanes $S$ were probed with a $\beta$-galactosidase cDNA, followed by a GFAP cDNA, representing a single-copy gene. BamHI sites at either end of the $\beta$-galactosidase gene (see $A$ ) generated a single $3.6 \mathrm{~kb}$ band in each line (lanes $B$ ), predicted from the structure of the transgene. DNA digested with EcoRI (lanes $R$ ), which cuts at a single site within the transgene, generated a $6.1 \mathrm{~kb}$ band in each line and an $8.5 \mathrm{~kb}$ band in line $1 E$, suggesting that two copies of the transgene lie tail to tail in line $1 E$ and indicate the independent origin of the two lines. A single $S s t \mathrm{I}$ cut within the transgene also generated a $6.1 \mathrm{~kb}$ band (lanes $S$ ), suggesting that tandem copies were inserted in each line. However, the different SstI banding patterns between the two lines (see lanes $S$ ) confirm the interpretation of independent insertion sites for the two transgenic lines. A comparison of the hybridization signal of the two SstI bands generated from the single-copy gene GFAP (arrows) was used to estimate a transgene copy number of three and five copies of the transgene per allele for the 1.3D and 1.3E lines, respectively. Molecular weight markers are shown on the left.

these analyses the enzyme activity reflected the difference in the transgene copy number between the lines. Also, at this level of analysis the results of the transgene expression in vivo were consistent with the preliminary in vitro transfection results, suggesting that the $1.3 \mathrm{~kb}$ promoter is not active in oligodendrocytes or cells in the immune system. In general, no tissue- or developmental-specific differences were noted in the expression of lac $Z$ in the two transgenic lines at any age (embryonic through adult) by this biochemical method. Neither were any differences noted in lac Z-stained cryostat sections of tissues. Thus, the observed patterns of transgene expression were independent of the integration site. Because of this, the photomicrographic data to follow will illustrate findings from both transgenic lines, interchangeably.

\section{The $1.3 \mathrm{~kb}$ golli promoter regulates expression in limited groups of neurons in the embryonic CNS}

Visual inspection of the transgenic embryos indicated that expression of the $\beta$-galactosidase reporter gene, under the control of the $1.3 \mathrm{~kb}$ golli promoter, was restricted significantly more than the endogenous golli gene. Figure $7 A$ shows an E11.5 transgenic mouse embryo that was fixed and stained with $\mathrm{X}$-gal to detect lac $Z$ activity. In this whole-mount embryo blue-stained cells were observed in relatively few regions of the nervous system; these included the OE and the developing OP. Very light staining, not evident in Figure $7 A$, was present in the spinal cord ganglia and in the telencephalon, areas that normally express the golli-mbp gene (for example, see Fig. 3). By E13.5, transgene expression was more intense, but it was localized primarily to specific regions within the brain and spinal cord (Fig. $7 B, C$ ). In the brain the transgene was expressed in the forebrain $(\mathrm{F})$, olfactory bulb $(\mathrm{OB})$, and $\mathrm{OE}$, regions in which endogenous golli mRNAs also are expressed (see Fig. 3C). Lac Z activity in neuronal groups and fibers emanating from the spinal cord and dorsal roots also overlapped areas of endogenous golli expression (compare Fig. $7 C$ with $3 A$ ) (cf. Landry et al., 1997). Thus the regulatory sequences within $1.1 \mathrm{~kb}$ upstream of tss 1 appeared to target expression to only four regions of the embryonic nervous system.

\section{The $1.3 \mathrm{~kb}$ golli-specific promoter targets lac $Z$ expression to preplate neurons}

Examination of golli transgene expression revealed an interesting pattern of cellular staining in the forebrain. Within the brains of E13.5 transgenic embryos, for example, lac $Z$ expression was confined to the forebrain and was more intense within the ventrolateral aspects of the telencephalon and significantly weaker 


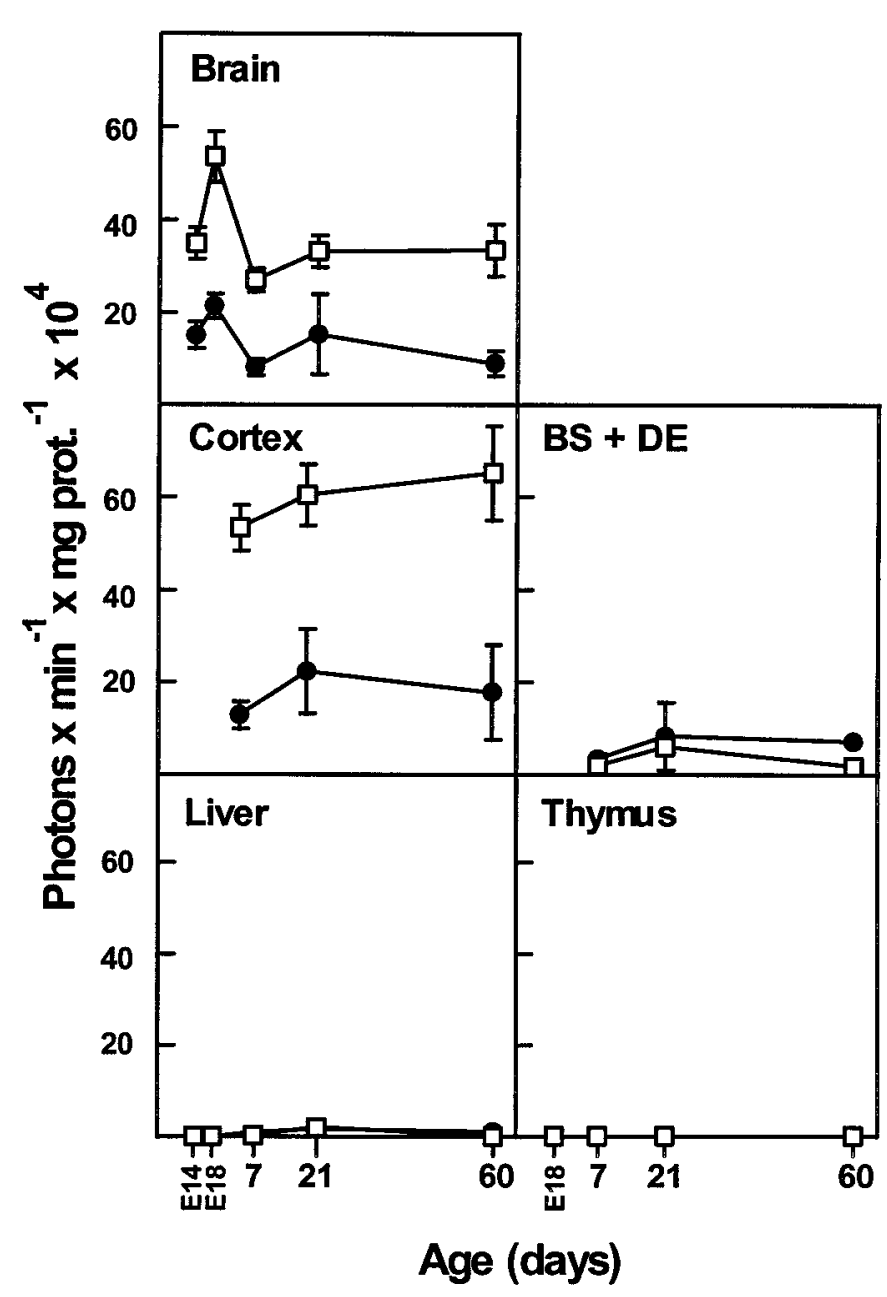

Figure 6. Tissue distribution and $\beta$-galactosidase activity in two transgenic lines during development. Significant $\beta$-galactosidase activity, measured in a luminescence assay at two embryonic (E14 and E18) and three postnatal $(P 7, P 21$, and $P 60)$ ages, was found only in the brain and primarily in the cortex in both strains of mice. The difference in $\beta$-galactosidase activities reflected the difference in the copy number of the transgene in the two lines. The data presented are the averages of three trials $\pm \mathrm{SD}$, performed in triplicate. 0 , Transgenic mouse line 1.3D; $\square$, Transgenic mouse line 1.3E. $B S$, Brainstem; $D E$, diencephalon.

toward the dorsomedial aspect (Fig. $8 A$ ). In sagittal sections cut through the telencephalon at several ages between E11.5 and E13.5, lac $Z$ staining was found to be confined to a discrete layer of cells, the primordial plexiform layer or preplate (PP) (Fig. 8B). Cells within the preplate constitute an early neuronal population that matures in a ventrolateral-to-dorsomedial direction (Smart, 1984; Bayer and Altman, 1990), which parallels the pattern of lac $Z$ staining that we observed within each hemisphere. This early neuronal cell layer also was found to express endogenous golli protein, as shown in Figure $4 D$. By E15.5, transgene expression was localized to the SP (Fig. $8 C$ ), but relatively few $\beta$-galimmunoreactive cells were evident in the $\mathrm{MZ}$ of the transgenic mice as compared with golli-expressing cells in this layer. Figure $8 D$ illustrates the colocalization of $\beta$-gal transgene activity and golli protein immunoreactivity within subplate neurons of the E15.5 transgenic brain.

In an attempt to define the cell types that expressed the transgene within the developing cortical plate, we performed double-labeling experiments with antibody to calretinin, a marker shown to be expressed in the pioneer neuronal populations of the telencephalon and, in particular, the Cajal-Retzius cells of the marginal layer (Soriano et al., 1994; Weisenhorn et al., 1994). Figure $8 E$ shows a double-stained section of brain tissue from E13.5 transgenic telencephalon that first was reacted with X-gal and then immunostained for calretinin. Many lac $Z$-stained cells colabeled with calretinin (some are indicated by arrows in Fig. $8 E$ ); however, other cells expressed lac $Z$ but did not stain with calretinin and most likely represent the earliest presubplate neurons. Conversely, calretinin-stained cells at the peripheral margin of the preplate did not stain with X-gal. It is likely that these cells correspond to Cajal-Retzius cells, suggesting that the $1.3 \mathrm{~kb}$ golli promoter is not active in all Cajal-Retzius cells but rather in a subpopulation of these cells. Interestingly, some lac Z-expressing cells of the size and morphology of Cajal-Retzius neurons could be detected in layer I as late as birth (data not shown).

\section{The $1.3 \mathrm{~kb}$ golli promoter targets expression to neurons in the deep cortical layers that persist into adulthood}

At P0, lac Z staining of the cortical subplate was observed in a discrete layer of cells directly above the intermediate zone (Fig. $9 A)$. By $\mathrm{P} 21$, as laminar definition and cortical maturation were completed, neurons that expressed the transgene continued to be confined primarily to the deep cortical layers (Fig. 9B). In P60 animals (Fig. 9C), lac $Z$-stained cells remained in this deep position, primarily in the lower aspects of cortical layer VI and just above the white matter tracts (corpus callosum).

Throughout development these lac Z-expressing cells possessed the characteristic morphology of neurons, including both radial (Fig. 10 $A$, dark arrows) as well as horizontal processes (Fig. $10 A$, open arrow). Expression of the transgene in neurons, and not in glia, in this region was established by double-labeling experiments in which tissue sections were stained first with X-gal and subsequently were immunostained. The lac $Z$-stained cells did not colocalize with GFAP-stained astrocytes (some of which are indicated by arrows in Fig. 10B) nor with astrocytes stained with S100 (data not shown). In contrast, many lac $Z$-stained cells colocalized with the neuron-specific markers tau (examples are indicated by arrows in Fig. 10C), neurofilament light chain (NFL), or MAP-2 (data not shown). We did not detect colocalization of X-gal staining with the oligodendrocyte-specific markers MBP or CNPase (data not shown). In complementary in vitro studies, primary cultures of mixed glial cells were prepared from the brains of newborn transgenic mice and examined for expression of the transgene. Lac $Z$ staining was observed only in a few contaminating neurons and never in any macro- or microglial cell type (data not shown). Thus lac $Z$ staining colocalized exclusively with neuronal markers, with no evidence of colocalization in any glial cell type.

\section{Neurons that express the transgene in postnatal brain are born during early corticogenesis}

To determine the birth date of neurons expressing the transgene in the deep cortical layers (layers V Ib-VII) of postnatal animals, we injected pregnant transgenic dams twice with BrdU, either at E10.5 and E11.5 or at E11.5 and E12.5. These injection dates approximate the ages at which subplate neurons are born in the mouse (Wood et al., 1992). At a number of ages after birth, brain sections from treated animals were stained with $\mathrm{X}$-gal to visualize cells expressing the transgene and then stained with antibody to 

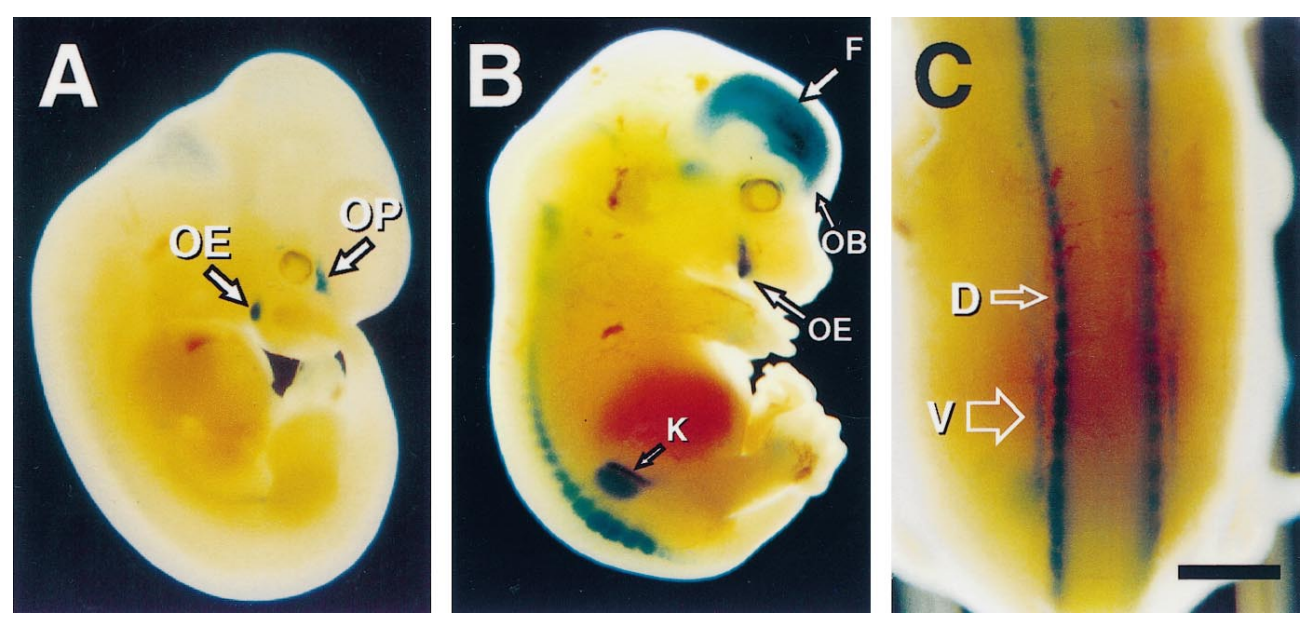

Figure 7. The golli proximal promoter is active in CNS neurons that normally express the gene during embryogenesis. $A$, Whole-mount E11.5 embryo from transgenic mouse line 1.3D stained with $\mathrm{X}$-gal. Expression of the lac $Z$ transgene was present in the olfactory placode $(O P)$ and olfactory epithelium $(O E)$. B, Whole-mount E13.5 embryo from transgenic mouse line 1.3D stained with X-gal. Expression of the lac $Z$ transgene was evident within the forebrain $(F)$, olfactory bulb $(O B)$, and olfactory epithelium $(O E)$. We also detected variable and inconsistent $\mathrm{X}$-gal staining in the kidney $(K)$, which was not investigated further. $C$, Dorsal view of an E13.5 embryo revealing expression of the lac $Z$ transgene in dorsal root ganglia $(D)$ and ventral root fibers $(V)$. Scale bar: in $A, 1.1 \mathrm{~mm}$; in $B, 1.9$ $\mathrm{mm}$; in $C, 1 \mathrm{~mm}$.
BrdU to identify cells born during the injection period. As shown in Figure 11, X-gal-stained cells within layers VIb-V II colocalized with BrdU-stained cells throughout the postnatal period that was examined. This indicates that transgene-expressing neurons in the postnatal subplate layer (VIb-VII) identified as late as 2 months after birth are born from E10.5-E12.5, the embryonic period in which subplate cells arise during corticogenesis.

\section{DISCUSSION}

\section{The MBP gene is expressed during embryonic brain development in pioneer neurons important in the formation of the cortex}

In this report we have extended our earlier work on the expression of golli products of the MBP gene in postnatal development to the embryonic nervous system. Golli protein was detected by immunocytochemistry at the earliest times we examined the embryos. In the E11.5 mouse brain, for example, golli protein was evident in superficial neurons of the tectum, neurons of the OP, and in cells of the OE. Within the forebrain, golli was present in Cajal-Retzius and subplate neurons and was expressed in the same pioneer neuronal populations as calretinin and reelin, proteins previously found to mark these early telencephalic cell populations. These studies permit us, then, to add golli proteins to the list of markers for this developmentally important set of neurons.

\section{A region $\sim 1 \mathrm{~kb}$ upstream of the first promoter of the MBP gene can target expression of a transgene to Cajal-Retzius cells and (pre-)subplate neurons}

A principal objective of this study was to begin to define genomic elements that regulate the expression of golli mRNAs and protein in neurons, in oligodendrocytes, and in the immune system. Preliminary in vitro data suggested that a region $\sim 1 \mathrm{~kb}$ upstream of tss1 might confer restricted expression on the gene. We therefore created transgenic mice in which the lac $Z$ gene was placed under the control of $1.3 \mathrm{~kb}$ of genomic sequence, including $1.1 \mathrm{~kb}$ directly upstream and 220 bp immediately downstream of tss1. In these mice, transgene expression was found in a subset of the neurons that normally express golli proteins. In this report we focused our attention on expression of the transgene in the developing telencephalon and forebrain, because the transgene marked a unique population of cortical pioneer neurons, the subplate neurons, in this region.

\section{Transgene expression was present in a population of neurons confined to the deepest cortical layers throughout development}

Lac $Z$ expression was evident within subplate neurons from their first appearance within the preplate and continued in a population of neurons within the deepest aspects of layer VI into adulthood. Within some of the cells of the subplate, transgene expression colocalized with calretinin, confirming by position and colabeling that cells expressing the transgene represent early developing neurons. As development proceeded, transgene expression persisted in cells directly below the expanding cortical plate, i.e., the subplate neurons. Transgene expression continued to be expressed in cells that possessed the morphology of subplate neurons and formed a distinct layer between the white matter and cortical layer VI as late as P60 (the oldest age examined in this study).

Bromodeoxyuridine experiments were performed to determine the birth date of the "blue" cells that were present in this layer in the brains of mature transgenic mice. Many of the cells within this deep cortical layer were "born" between E10.5 and E12.5, the period that subplate neurons are thought to be born in the mouse (Wood et al., 1992). The persistence of subplate neurons in the postnatal rodent cortex has been controversial (Valverde et al., 1995; Price et al., 1997), in part because of the lack of suitable markers for these cells. The transgene-expressing cells may represent subplate neurons that survive beneath cortical layer VI well into postnatal life. These results are consistent with those of Valverde et al. $(1989,1995)$ and Reep and Goodwin (1988), who have shown that neurons born between E11-E13 (E12-E14 in the rat) persist in significant numbers in a deep cortical layer, which they call layer VII, as late as P60 in rodents.

\section{Although golli proteins appear to be a marker for Cajal-Retzius neurons, the lac $Z$ transgene was expressed only in a subset of these cells}

The Cajal-Retzius and subplate cells arise from the same group of cells in the primordial plexiform layer, and in our studies these cells appeared to be immunostained generally with the golli antibody. After this layer was split into the MZ and SP, golli immunostaining clearly delineated both of these layers. In the transgenic mice, in contrast, only some cells within the marginal layer of the cortex continued to express lac $Z$ as late as P0. These cells represented only a small proportion of the neurons that 



Figure 8. Expression of the lac $Z$ transgene in the embryonic forebrain follows the maturation of preplate neurons. $A$, A ventral view of the head of an E13.5 embryo (line 1.3D) illustrating the expression of the lac $Z$ transgene. Note the pronounced lateral-to-medial and rostral-to-caudal gradient of staining. $B$, A sagittal section through the telencephalon of an X-gal-stained E13.5 transgenic embryo (line 1.3D). The blue X-gal reaction product was confined to cells within the preplate $(P P)$ but was not evident in neuroepithelium $(N E)$. Dorsal $(D)$ and rostral $(R)$ orientation markers are indicated. $C$, Sagittal section from an E15.5 embryo (line 1.3E) that was immunostained for $\beta$-galactosidase. Numerous stained neurons were evident in the subplate $(S P)$, although only a few stained cells (arrow) were present in the marginal zone $(M Z)$. The cortical plate $(C P)$ was not stained. $D$, Sections from E15.5 transgenic brain, which were stained first with X-gal (blue) and then were immunostained for golli protein, showed colabeled neurons (arrows) within the subplate $(S P)$. E, A section from E13.5 transgenic mouse (line 1.3E) telencephalon stained with X-gal and immunostained for calretinin, a marker of early telencephalic neuronal populations. Some of the calretinin-positive neurons in the preplate $(P P)$ colocalized with $\beta$-gal $($ arrows). Scale bar: in $A, 1$ mm; in $B, 180 \mu \mathrm{m}$; in $C, 40 \mu \mathrm{m}$; in $D, 15 \mu \mathrm{m}$; in $E, 35 \mu \mathrm{m}$. 

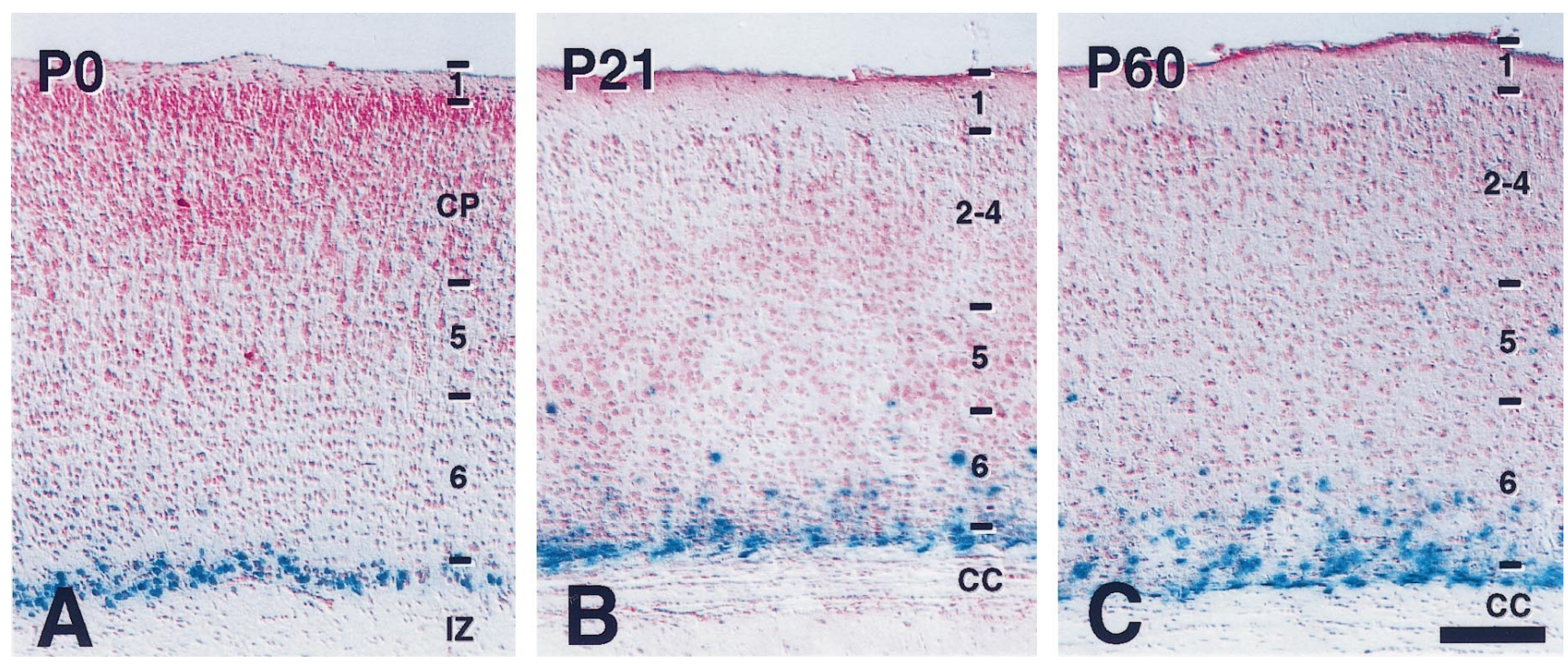

Figure 9. Lac $Z$ expression persisted within the deep cortical layers of transgenic mice forebrain during postnatal development. $A$, Coronal sections from neonatal transgenic mice $(P O)$ were stained for $\beta$-galactosidase activity. Note the narrow layer of stained cells corresponding to the subplate just above the intermediate zone $(I Z)$. Sections were counterstained with Nissl stain, pyronin Y. $C P$, Cortical plate. $B$, At $P 21, \mathrm{X}$-gal staining continued to be confined to deep cortical layers throughout the cortex. $C C$, Corpus callosum. $C$, At $P 60$, transgene expression persisted within cortical layers VIb-V II. Scale bar: in $A, 100 \mu \mathrm{m}$; in $B, C, 170 \mu \mathrm{m}$.
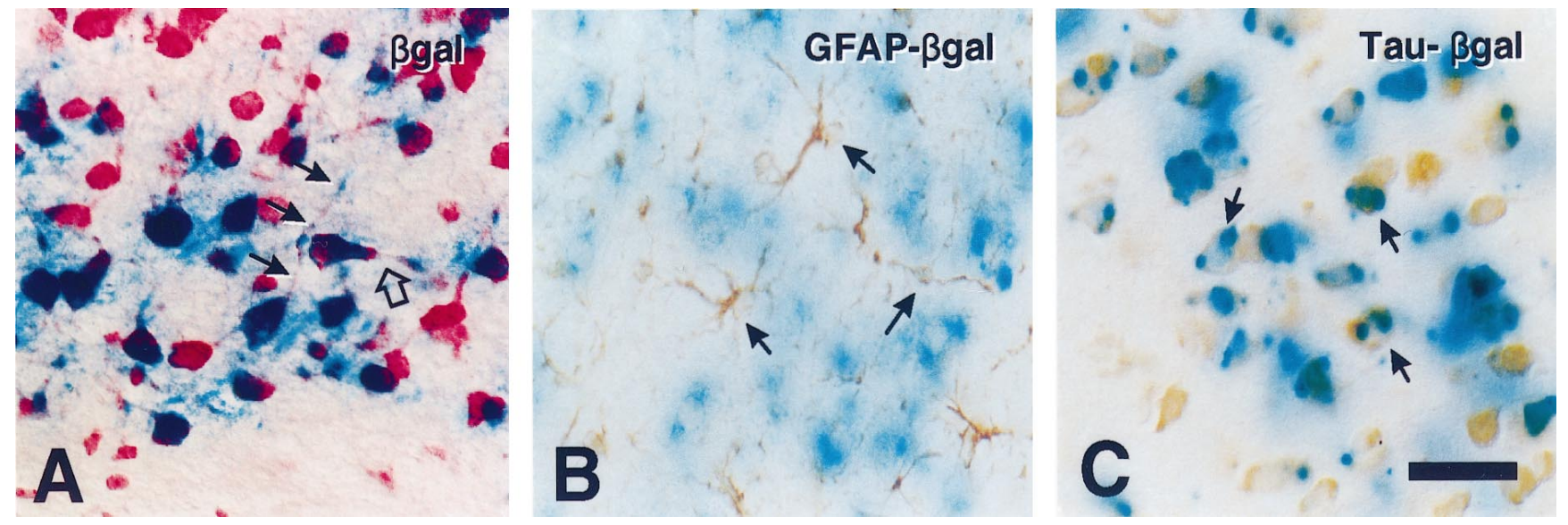

Figure 10. Golli transgene expression is confined to neurons within deep cortical layers. $A$, A section of $\mathrm{P} 7$ transgenic mouse brain stained with $\mathrm{X}$-gal and then counterstained with pyronin Y. X-gal product was confined to cells with the morphology of neurons and was identified within both radial (dark arrows) and horizontal (open arrow) processes. B, A section from P21 mouse brain stained for $\beta$-galactosidase, followed by immunostaining for the astrocyte marker GFAP. GFAP-stained astrocytes (arrows) did not stain with X-gal substrate. $C$, An adjacent section from the same P21 transgenic mouse brain stained with X-gal, followed by immunostaining for the neuronal marker tau. The arrows indicate some of the neurons that express both $\beta$-gal and tau proteins. Depending on the angle and plane of cutting, the cytoplasmic X-gal staining appears on either side of the neuronal nucleus. Scale bar: in $A, 20 \mu \mathrm{m}$; in $B, C, 25 \mu \mathrm{m}$.

could be immunostained with golli and other markers of CajalRetzius neurons within the marginal layer. This suggests that the transgene is expressed in a subset of Cajal-Retzius neurons and that expression tapers off with development, unlike the transgene expression pattern observed in subplate neurons.

\section{The $1.3 \mathrm{~kb}$ golli promoter and neuron-specific promoters}

The $1.3 \mathrm{~kb}$ tss1 (golli) promoter drives transgene expression in the nervous system to select groups of neurons with a specificity that almost approaches that of the tss3 (MBP) promoter, which drives expression exclusively to myelin-forming cells, i.e., oligo- dendrocytes and Schwann cells. The onset of lac $Z$ expression occurred at approximately E11, demonstrating that the $1.3 \mathrm{~kb}$ golli promoter region preserved the correct temporal pattern of gene expression within those neurons. The promoter targeted developmentally accurate expression to some Cajal-Retzius cells and (pre-)subplate neurons, among the earliest maturing neurons in the CNS.

In an effort to understand the mechanisms of neuronal development and specialization, researchers have shown considerable interest in neuron-specific promoters and regulatory elements that might target genes to neurons (Mandel and McKinnon, 1993; 

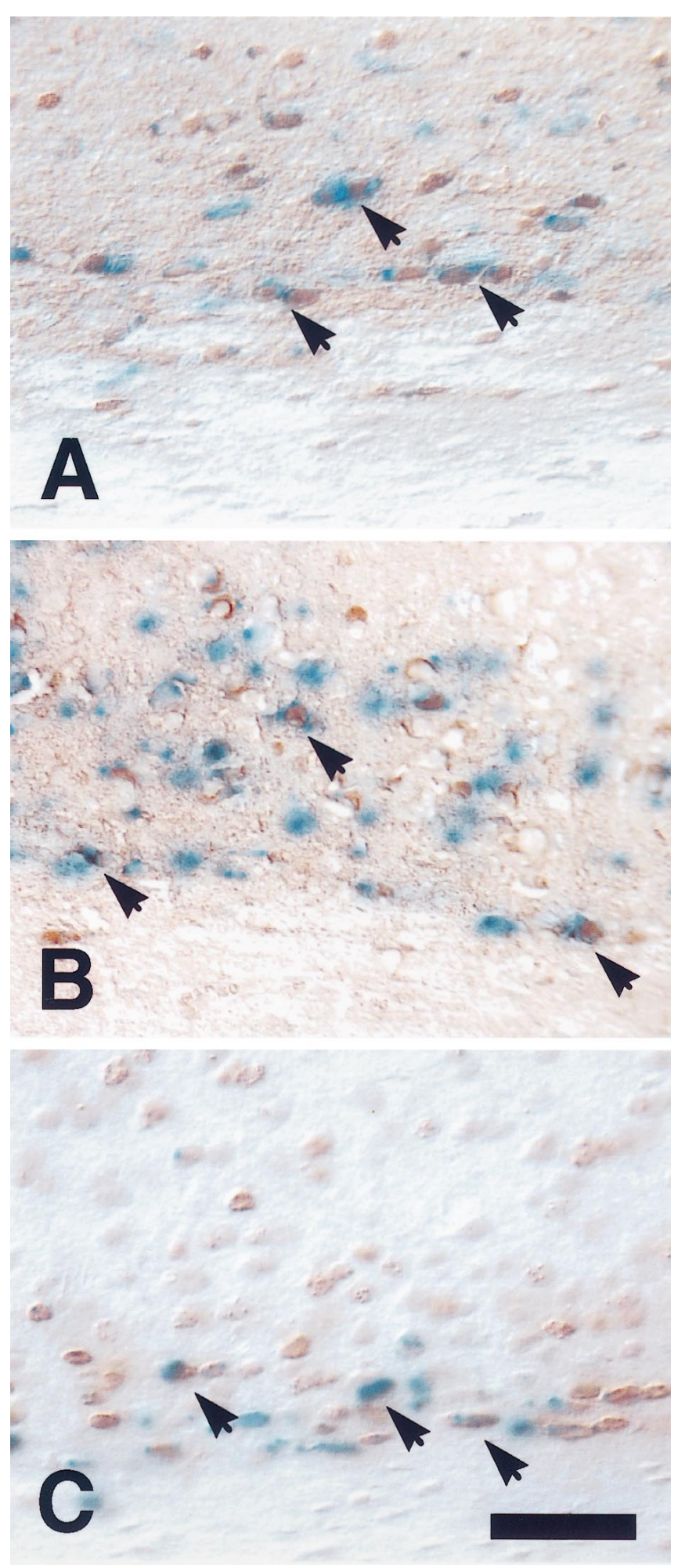

Figure 11. Neurons expressing the golli transgene in the deep layers of postnatal cortex are born between E10.5 and E12.5. Pregnant dams were injected with BrdU on two embryonic days, either E10.5 and E11.5 or E11.5 and E12.5. Coronal forebrain sections from the progeny of these animals were stained with X-gal for golli transgene activity and with antibody to BrdU to determine birth dating. Shown are sections from $(A)$ a P23 animal (E10.5-E11.5 injection), $(B)$ a P23 animal (E11.5-E12.5 injection), and $(C)$ a P50 animal (E10.5-E11.5 injection). The arrows in each panel indicate neurons in layer VIb-VII that were both BrdUpositive (brown) and lac Z-positive (blue). The corpus callosum is the unstained area at the bottom of each panel. Scale bar for $A-C, 40 \mu \mathrm{m}$.
Levitt et al., 1997). Many of the promoters that have been examined have been unable to confer spatial or temporal specificity to the transgene (Cohen-Tannoudji et al., 1994; Clegg et al., 1996; Jones et al., 1996; Walters et al., 1996), and very few have precisely targeted embryonic neurons (Smeyne et al., 1991; Matsuo et al., 1993). Two of the best examples of neuron-specific targeting have been promoter elements of the NF-L (Charron et al., 1995) and dopamine- $\beta$-hydroxylase genes (Hoyle et al., 1994). They maintain neuronal specificity and also approach the temporal patterns exhibited by the endogenous genes. Of the neuronspecific promoter studies to date, almost none have exhibited the restricted expression of $1.3 \mathrm{~kb}$ golli promoter and none have targeted expression to the two sets of cortical pioneer neurons described in this study.

\section{A new conceptualization of the myelin basic protein gene}

In many respects the MBP gene is unique in biology. It is among a relatively small group of genes $>100 \mathrm{~kb}$ in length, and it represents an example of both two "overlapping" genes as well as a "gene within a gene." In this respect it bears some resemblance to the neurofibromatosis gene in that both genes are large transcription units that encompass smaller genes (Xu et al., 1990; Viskochil et al., 1991). However, they are distinctly different in that the smaller MBP and BG21/J37 portions of the MBP gene are not simply included within an intron of the larger gene but share alternatively spliced exons in common. This type of alternative splicing in overlapping transcription units of this size is very unusual and represents a situation for which there are few examples in biology.

Another unusual feature of the MBP gene is its regulation. The MBP transcription start site (tss3) is under very tight developmental control and is expressed only in myelin-forming cells. Most of this regulation resides within the exon $5 \mathrm{~A}$ region upstream of tss3 (Goujet-Zalc et al., 1993). Clearly, the golli tss1 is under less specific regulation. There appears to be a gradient of cell and tissue specificity among the three promoters of the gene, with the most downstream promoter being specific to myelinforming cells and the most upstream promoter exhibiting the least tissue and cell specificity.

This combination of structure and expression changes significantly our conception of the MBP gene, which generally has been thought to be strikingly specific for myelin-forming cells. Indeed, the genomic region encompassing exon $5 \mathrm{~A}$ has been used by many investigators to target transgenes specifically to oligodendrocytes. We now find that this "myelin" gene is expressed in many neuronal populations, some of which are important in establishing the structure of the cerebral cortex. In addition, we have found that increased expression of this gene within the immune system may be responsible for the relapsing disease phase of experimental autoimmune encephalomyelitis, an animal model of multiple sclerosis (MacKenzie-Graham et al., 1997). Thus, it has become clear that the MBP gene is important to neurons and immune cells as well as oligodendrocytes and must perform a function that is not associated with myelination.

In summary, this work has contributed to an evolving concept of the MBP gene as one with broader functions in neurons and in myelin-forming cells in the nervous system. It has identified a region upstream of the first transcription start site that can target transgenes to a very limited number of neurons, including the earliest-forming neurons in the cortex. From this work has 
emerged a transgenic mouse that will be important for future studies on determining the fate and function of subplate neurons.

\section{REFERENCES}

Bayer SA, Altman J (1990) Development of layer I and the subplate in the rat neocortex. Exp Neurol 107:48-62.

Campagnoni AT, Pribyl TM, Campagnoni CW, Kampf K, AmurUmarjee S, Landry CF, Handley VW, Newman SL, Garbay B, Kitamura K (1993) Structure and developmental regulation of golli-mbp, a $105 \mathrm{~kb}$ gene that encompasses the myelin basic protein gene and is expressed in cells in the oligodendrocyte lineage in the brain. J Biol Chem 268:4930-4938.

Campagnoni CW, Kampf K, Mason B, Handley VW, Campagnoni AT (1994) Isolation and characterization of a cDNA encoding the zebra finch myelin proteolipid protein. Neurochem Res 19:1061-1065.

Charron G, Guy L-G, Bazinet M, Julien J-P (1995) Multiple neuronspecific enhancers in the human neurofilament light chain. J Biol Chem 270:30604-30610.

Clegg CH, Haugen HS, Boring LF (1996) Promoter sequences in the RI $\beta$-subunit gene of cAMP-dependent protein kinase required for transgene expression in mouse brain. J Biol Chem 271:1638-1644.

Cohen-Tannoudji M, Babinet C, Wassef M (1994) Early determination of a mouse somatosensory cortex marker. Nature 368:460-463.

Danielson PE, Forss-Petter S, Brow MA, Calavetta L, Douglass J, Milner RJ, Sutcliffe JG (1988) p1B15: a cDNA clone of the rat mRNA encoding cyclophilin. DNA 7:261-267.

D'Arcangelo G, Miao GG, Chen SC, Soares HD, Morgan JI, Curran T (1995) A protein related to extracellular matrix proteins deleted in the mouse mutant reeler. Nature 374:719-723.

Ellison JA, Scully SA, de Vellis J (1996) Evidence for neuronal regulation of oligodendrocyte development: cellular localization of plateletderived growth factor $\alpha$-receptor and A-chain mRNA during cerebral cortex development in the rat. J Neurosci Res 45:28-39.

Feinberg AP, Vogelstein B (1983) A technique for radiolabeling DNA restriction endonuclease fragments to high specific activity. Anal Biochem 132:6-13.

Fonseca M, del Rio JA, Martinez A, Gomez S, Soriano E (1995) Development of calretinin immunoreactivity in the neocortex of the rat. J Comp Neurol 361:177-192.

Fritz RB, Kalvakolanu I (1995) Thymic expression of the golli-myelin basic protein gene in the SJL/J mouse. J Neuroimmunol 57:93-99.

Goujet-Zalc C, Babinet C, Monge M, Timsit S, Cabon F, Gansmuller A, Miura M, Sanchez M, Pournin S, Mikoshiba K, Zalc B (1993) The proximal region of the MBP gene promoter is sufficient to induce oligodendroglial-specific expression in transgenic mice. Eur J Neurosci 5:624-632.

Hoyle GW, Mercer EH, Palmiter RD, Brinster RL (1994) Cell-specific expression from the human dopamine $\beta$-hydroxylase promoter in transgenic mice is controlled via a combination of positive and negative regulatory elements. J Neurosci 14:2455-2463.

Jacobson L (1987) Purification and fractionation of poly $\left(\mathrm{A}^{+}\right)$RNA. In: Methods in enzymology, Vol 152, Guide to molecular cloning techniques (Berger SI, Kimmel AR, eds), pp 254-261. San Diego: Academic.

Jones A, Bahn S, Grant AL, Kohler M, Wisden W (1996) Characterization of a cerebellar granule cell-specific gene encoding the $\gamma$-amino butyric acid type A receptor $\alpha 6$ subunit. J Neurochem 67:907-916.

Landry CF, Ellison JA, Pribyl TM, Campagnoni C, Kampf K, Campagnoni AT (1996) Myelin basic protein gene expression in neurons: developmental and regional changes in protein targeting within neuronal nuclei, cell bodies, and processes. J Neurosci 16:2452-2462.

Landry CF, Ellison JA, Skinner E, Campagnoni AT (1997) Golli-MBP proteins mark the earliest stages of fiber extension and terminal arboration in the mouse peripheral nervous system. J Neurosci Res 50:265-271.

Levitt P, Barbe MF, Eagleson KL (1997) Patterning and specification of the cerebral cortex. Annu Rev Neurosci 20:1-24.

Macdonald RJ, Swift GH, Przybyla AE, Chirgwin JM (1987) Isolation of RNA using guanidinium salts. In: Methods in enzymology, Vol 152, Guide to molecular cloning techniques (Berger SI, Kimmel AR, eds), pp 219-227. San Diego: Academic.
MacKenzie-Graham AJ, Pribyl TM, Kim S, Porter VR, Campagnoni AT, Voskuhl RR (1997) Myelin protein expression is increased in lymph nodes of mice with relapsing experimental autoimmune encephalomyelitis. J Immunol 159:4602-4610.

Mandel G, McKinnon D (1993) Molecular basis of neural-specific gene expression. Annu Rev Neurosci 16:323-345.

Matsuo K, Ikeshima H, Shimoda K, Umezawa A, Hata J, Maejima K, Nojima H, Takano T (1993) Expression of the rat calmodulin gene II in the central nervous system: a 294-base promoter and 68-base leader segment mediates neuron-specific gene expression in transgenic mice. Mol Brain Res 20:9-20.

Ogawa M, Miyata T, Nakajima K, Yagyu K, Seike M, Ikenaka K, Yamamoto H, Mikoshiba K (1995) The reeler gene-associated antigen on Cajal-Retzius neurons is a crucial molecule for laminar organization of cortical neurons. Cell 14:899-912.

Pribyl TM, Campagnoni CW, Kampf K, Kashima T, Handley VW, McMahon J, Campagnoni AT (1993) The 179 kilobase human golli$m b p$ gene: structure and expression in the immune and central nervous systems. Proc Natl Acad Sci USA 90:10695-10699.

Pribyl TM, Campagnoni CW, Kampf K, Ellison JA, Landry CF, Kashima T, McMahon J, Campagnoni AT (1996a) Expression of the myelin basic protein gene locus in neurons and oligodendrocytes in the human fetal central nervous system. J Comp Neurol 374:342-353.

Pribyl TM, Campagnoni CW, Kampf K, Handley VW, Campagnoni AT (1996b) Expression of major myelin proteins in the human thymus. J Neurosci Res 45:812-819.

Price DJ, Aslam S, Tasker L, Gillies K (1997) Fates of the earliest generated cells in the developing murine neocortex. J Comp Neurol 377:414-422.

Reep RL, Goodwin GS (1988) Layer VII of rodent cerebral cortex. Neurosci Lett 90:15-20.

Smart IH (1984) Histogenesis of the mesocortical area of the mouse telencephalon. J Anat 138:537-552.

Smeyne RJ, Oberdick J, Schilling K, Berrebi AS, Mugnaini E, Morgan JI (1991) Dynamic organization of developing Purkinje cells revealed by transgene expression. Science 254:719-721.

Soriano E, Del Rio JA, Martinez A, Super H (1994) Organization of the embryonic and early postnatal murine hippocampus. I. Immunocytochemical characterization of neuronal populations in the subplate and marginal zone. J Comp Neurol 342:571-595.

Valverde F, Vacal-Valverde MV, Santacana M, Heredia M (1989) Development and differentiation of early generated cells of sublayer $\mathrm{VIb}$ in the somatosensory cortex of the rat: a correlated Golgi and autoradiographic study. J Comp Neurol 290:118-140.

Valverde F, Lopez-Mascaraque L, Santacana M, De Carlos JA (1995) Persistence of early-generated neurons in the rodent subplate: assessment of cell death in neocortex during the early postnatal period. J Neurosci 15:5014-5024.

Verity AN, Bredesen D, Vonderscher C, Handley VW, Campagnoni AT (1993) Expression of myelin protein genes and other myelin components in an oligodendrocytic cell line conditionally immortalized with a temperature-sensitive retrovirus. J Neurochem 60:577-587.

Viskochil D, Cawthon R, O'Connell P, Xu GF, Stevens J, Culver M, Carey J, White R (1991) The gene encoding the oligodendrocytemyelin glycoprotein is embedded within the neurofibromatosis type 1 gene. Mol Cell Biol 11:906-912.

Walters E, Grillo M, Tarazzo G, Stein-Izsak C, Corbin J, Bocchiaro C, Margolis FL (1996) Proximal regions of the olfactory marker protein gene promoter direct olfactory neuron-specific expression in transgenic mice. J Neurosci Res 43:146-160.

Weisenhorn DM, Prieto E, Celio MR (1994) Localization of calretinin in cells of layer I (Cajal-Retzius cells) of the developing cortex of the rat. Brain Res Dev Brain Res 82:293-297.

Wood JG, Martin S, Price DJ (1992) Evidence that the earliest generated cells of the murine cerebral cortex form a transient population in the subplate and marginal zone. Brain Res Dev Brain Res 66:137-140.

Xu GF, O'Connell P, Viskochil D, Cawthon R, Robertson M, Culver M, Dunn D, Stevens J, Gesteland R, White R, Weiss R (1990) The neurofibromatosis type 1 gene encodes a protein related to GAP. Cell 62:599-608. 